\title{
Flavor and Metabolite Profiles of Meat, Meat Substitutes, and Traditional Plant-Based High-Protein Food Products Available in Australia
}

\author{
Kornelia Kaczmarska ${ }^{1}\left(\mathbb{D}\right.$, Matthew Taylor ${ }^{2, *} \mathbb{D}$, Udayasika Piyasiri ${ }^{1}$ and Damian Frank ${ }^{1,3, *}$ \\ 1 CSIRO Agriculture and Food, North Ryde, NSW 2113, Australia; korneliak85@hotmail.com (K.K.); \\ battagodage.p@gmail.com (U.P.) \\ 2 CSIRO Land \& Water, Canberra, ACT 2601, Australia \\ 3 Centre for Advanced Food Enginomics, The University of Sydney, Sydney, NSW 2006, Australia \\ * Correspondence: m.taylor@csiro.au (M.T.); damian.frank@sydney.edu.au (D.F.); Tel.: +61-2-6246-4404 (M.T.)
}

check for

updates

Citation: Kaczmarska, K.; Taylor, M.;

Piyasiri, U.; Frank, D. Flavor and

Metabolite Profiles of Meat, Meat

Substitutes, and Traditional

Plant-Based High-Protein Food

Products Available in Australia. Foods

2021, 10, 801. https://doi.org/

10.3390 /foods 10040801

Academic Editor: Sandra

Sofia Quinteiro Rodrigues

Received: 23 February 2021

Accepted: 6 April 2021

Published: 8 April 2021

Publisher's Note: MDPI stays neutral with regard to jurisdictional claims in published maps and institutional affiliations.

Copyright: (C) 2021 by the authors Licensee MDPI, Basel, Switzerland. This article is an open access article distributed under the terms and conditions of the Creative Commons Attribution (CC BY) license (https:// creativecommons.org/licenses/by/ $4.0 /)$

\begin{abstract}
Demand for plant-based proteins and plant-based food products is increasing globally. This trend is driven mainly by global population growth and a consumer shift towards more sustainable and healthier diets. Existing plant-based protein foods and meat mimetics often possess undesirable flavor and sensory properties and there is a need to better understand the formation of desirable meat-like flavors from plant precursors to improve acceptance of novel high-protein plant foods. This study aimed to comprehensively characterize the non-volatile flavor metabolites and the volatiles generated in grilled meat (beef, chicken, and pork) and compare these to commercially available meat substitutes and traditional high-protein plant-based foods (natto, tempeh, and tofu). Solid phase microextraction with gas-chromatography mass-spectrometry was used for elucidation of the flavor volatilome. Untargeted characterization of the non-volatile metabolome was conducted using Orbitrap mass spectrometry and Compound Discoverer ${ }^{\mathrm{TM}}$ datamining software. The study revealed greater diversity and higher concentrations of flavor volatiles in plant-based foods in comparison to grilled meat, although the odor activity of specific volatiles was not considered. On average, the total amount of volatiles in plant-based products were higher than in meat. A range of concentrations of free amino acids, dipeptide, tripeptides, tetrapeptides, nucleotides, flavonoids, and other metabolites was identified in meat and plant-based foods.
\end{abstract}

Keywords: plant-based; meat; volatilome; metabolomics; protein

\section{Introduction}

Increased consumer concern about environmental sustainability, animal welfare, and health impacts of high meat consumption are important factors influencing the increasing demand for traditional high-protein plant-based alternatives and more recent faux-meat or mimetic-meat substitutes [1,2]. With increased demand for alternative non-animal sources of protein, and a consumer-led movement towards flexitarian and more sustainable diets, it is essential to better understand the potential for formation of desirable flavors from plant protein precursors to improve formulations of novel high-protein plant foods, especially those that attempt to replicate meat-like flavor attributes. While the flavor profiles of meats such as beef, chicken, or pork have been extensively characterized in literature [3-10], the flavor of high-protein plant-based products and meat substitutes have not been extensively investigated or reported.

Meats from animal muscles and organs are an excellent source of high-quality complete protein and can also be a source of fats and important micronutrients such as zinc, iron, and vitamin B12 [11]. Meat in its raw form has a relatively mild flavor and needs to be subjected to thermal processing (mainly frying, grilling, and roasting) to promote complex Maillard and Strecker degradation reactions and oxidation of lipids, leading to typical meat 
flavor and aroma formation [12,13]. Small molecules including free amino acids, peptides, nucleotides, sugars, acids, and thiamine (vitamin B1) are important meat flavor precursors in Maillard, Strecker, and other reactions [14], and also contribute to the development of desirable meaty, savory, umami $[15,16]$, and kokumi $[17,18]$ taste. The intramuscular fat present in meat also plays a critical role in the formation of characteristic volatile aroma compounds and delivery of flavor, as well as the juiciness and mouthfeel of meat $[3,19,20]$. Overconsumption of processed and red meat is potentially linked to negative health effects, such as cardiovascular disease, diabetes, and cancer [21]. Multiple factors influence the decision to consume meat and probably also other non-animal high-protein foods: an intrinsic human desire for the energy and satiety associated with high-protein and nutrient-rich foods [22]; cultural and social factors; affordability; availability and convenience; umami taste and savory flavor; and other drivers [23,24].

Traditional high-protein soy-based foods like tofu, tempeh, and natto have been widely consumed in Asia for centuries. These foods are produced using microorganisms to preserve, modify, and/or improve the digestibility and sensory acceptance of the final product; however, tofu is normally produced in the West by chemical precipitation of protein rather than the use of microorganisms. Recently, alternative legumes and/or grains (lupin, faba) are also being used in the production of these foods [25,26]. The nutritional and health promoting properties of tofu, tempeh, natto, and other traditional fermented Asian foods are receiving more attention around the world [27]. Apart from being good sources of protein, some of these fermented products may also provide bioactive peptides, vitamins, phytochemicals, dietary fiber, and other metabolites that contribute to the functional benefits of these traditional plant-based foods [27]. The distinctive flavor profiles of fermented foods are mainly due to the enzymatic activity of microorganisms which break down the protein (proteolysis) into smaller peptide fragments and free amino acids as well as breaking down complex carbohydrates into more simple molecules such as sugars [28]. Among the most important flavor-active compounds in hydrolyzed foods, free amino acids, nucleotides, peptides, and their derivatives provide umami and kokumi molecules and impart associated desirable sensory properties $[18,29,30]$. Tofu, tempeh, and natto are nutritious sources of high-quality protein and are often used as alternatives to meat or fish [31]. Natto has very distinctive sensory properties; the flavor is described as soy sauce, sour, nutty, and chocolate-like and the soybeans develop a unique sticky mucilaginous surface texture produced by Bacillus subtilis natto fermentation [32,33]. Raw tempeh has a pleasant slightly fermented odor and after grilling or frying at high temperatures, tempeh may develop desirable "meaty" and "nutty" flavor notes [31]. Tofu is produced through soymilk coagulation using salts, and has a mild and bland flavor which is not meaty at all. When tofu is fried or grilled, Maillard and other high temperature reactions occur on the surface, bringing about only mild savory and nutty flavors [34].

"Fake"- or "faux"-meat substitutes are manufactured foods that attempt to replicate the organoleptic (flavor, texture, mouthfeel) and nutritional content (protein, iron, B12 content) of specific types of meat (beef, chicken, or pork) [35]. They utilize non-meat protein sources including mainly texturized soy and other legumes such as pea protein, nuts, cereal, vegetables, and mycoproteins. Texturized soy protein (TSP) is the most common protein component of commercially available plant-based meat alternatives, which are becoming more popular around the world [36]. The soybean protein used to create TSP usually has undergone significant processing to partially purify the protein fraction and remove lipids and to inactivate lipoxygenase activity. Soybeans have a relatively high fat content, and lipoxygenase derived volatiles such as 2-pentylfuran and others are linked to undesirable beany off flavors $[37,38]$. Good quality TSP generally has a neutral and bland flavor profile and requires the addition of flavor precursors and/or Maillard flavors to create products that taste convincingly meat-like. Globally, the meat substitute market is growing fast, and demand for sustainable, nutritious, and palatable meat substitutes is increasing rapidly [23].

This study aimed to map the essential non-volatile flavor precursors-free amino acids, nucleotides, small peptides, and other small metabolites—and grilled volatile flavor 
characteristics of commercially available meats (beef, chicken, and pork) and compare them to commercially available meat substitutes and traditional high-protein plant-based foods-natto, tempeh, and tofu available in Australian supermarkets (Sydney).

\section{Materials and Methods}

\subsection{Chemicals}

All chemicals were purchased from Sigma Aldrich (Castle Hill, NSW, Australia) except where stated otherwise. Reference volatiles were used to confirm the identity of the following: Acetic acid, butanoic acid, isovaleric acid, hexanoic acid, ethanol, 1octen-3-ol, 2-phenylethylalcohol, acetaldehyde, 2-methylbutanal, 3-methylbutanal, (E,E)2,4-hexadienal, ethyl acetate, methyl butanoate, ethyl hexanoate, benzaldehyde, 2,3pentanedione, 2-pentylfuran, acetone, 2-butanone, 2-heptanone, 2-octanone, 2-hydoxy3-butanone, trimethyl pyrazine, methyl pyrazine, dimethyl disulfide, carbon disulfide, methional, 2,3-butanedione, 2-ethylfuran, 2-heptanone, dimethyl disulfide, hexanal, 1butanol, 1-pentanol, methylpyrazine, octanal, 1-octen-3-one, 2,5-dimethylpyrazine, 2,6dimethylpyrazine, 1-hexanol, dimethyl trisulfide, nonanal, $(E)-2$-nonenal, 3-ethyl-2,5dimethylpyrazine, 1-octen-3-ol, methional, $(E)$-2-nonenal, $(E, E)$-2,4-decadienal, guaiacol, $p$-cresol, 2-ethylthiophene, and 4-methyl-1-pentanol (internal standard). The following standards were used to confirm the identity of non-volatile compounds: L-aspartic acid, asparagine, L-alanine, creatine, carnosine, carnitine, glutamic acid, glutamine, glycine, L-histidine, L-lysine, L-leucine, L-methionine, L-ornithine, tryptophan, L-tyrosine, Lthreonine, D-serine, valine, phenylalanine, L-(+)-proline, and nucleotides and their derivatives cytidine, guanosine monophosphate, guanine, guanosine, hypoxanthine, inosine monophosphate, inosine, uracil, uridine, and xanthine.

Ammonium formate, acetonitrile, methanol, formic acid, and positive and negative ion calibrant solutions (Pierce LTQ Velos ESI) were purchased from Thermo Fisher Scientific (Mulgrave, VIC, Australia).

\subsection{Materials}

A total of 30 products were used in the study. Each product was analyzed in triplicate. Ten commercially available plant-based meat substitutes (MS) were investigated. The meat substitutes were selected based on being described as having typical meat flavor: Five faux-"beef" burgers, two faux-"beef" mince, two faux-"beef" sausages, and one faux"pork" roast. It should be noted that there are many plant-based products (not examined in this study) that do not attempt to imitate meat flavor at all; for some consumers typical meat flavor and texture is not considered desirable. Four samples of tempeh (T), one made from traditional soy and the others made from alternative legumes; two samples of soft or firm tofu (TO); five samples of natto (N), raw and cooked (NC); three beef (B) samples, including regular mince, premium mince, and steak (scotch fillet); three chicken samples (C), including breast premium thigh; and three pork (P) samples, including sirloin steak, loin steak, and cutlet, were purchased from local supermarkets. Natto $(\mathrm{N})$ was locally obtained from an Asian grocery store. The type of product, main ingredients, and nutritional information (available from the original packaging) are presented in Table 1.

\subsection{Sample Preparation and Cooking Protocol}

Chilled meat samples were removed from retail packaging and minced into small pieces using a hand-blender, and patties were formed $(\sim 20 \mathrm{~g})$ and pan-fried (non-stick coating frypan, Mascot, NSW, Australia) using an induction cooktop set to $\sim 200{ }^{\circ} \mathrm{C}$ (Electrolux, Mascot, NSW, Australia) for 2 min each side or until an internal temperature of $75^{\circ} \mathrm{C}$ was reached, measured with a wire thermocouple (FoodPro Plus, Fluke, Baulkham Hills, NSW, Australia). Tempeh and tofu were fried for 8 or 10 min each side, respectively, or until golden. Natto samples were analyzed either uncooked or fried for 8 min each side or until golden. 
Table 1. Nutrition information of meats, meat substitutes, and traditional plant-based high-protein products.

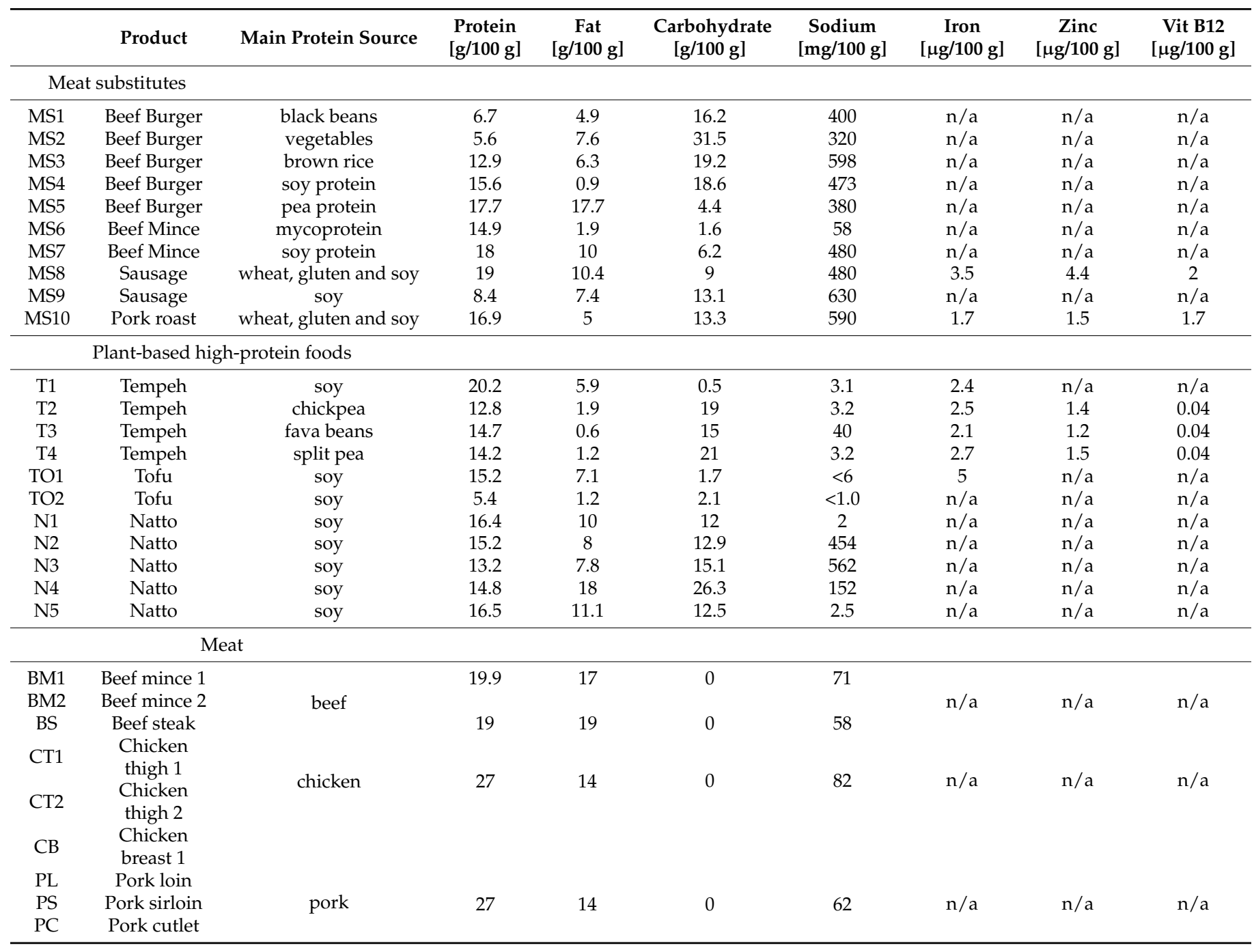

MS = Meat Substitute, $\mathrm{T}=$ Tempeh, $\mathrm{TO}=$ Tofu, $\mathrm{N}=$ Natto, $\mathrm{BM}=$ Beef Mince, $\mathrm{BS}=$ Beef Steak, $\mathrm{CT}=$ Chicken Thigh, $\mathrm{CB}=\mathrm{Chicken}$ Breast, $\mathrm{PL}$ $=$ Pork Loin, $\mathrm{PS}=$ Pork Sirloin, $\mathrm{PC}=$ pork cutlet, $\mathrm{n} / \mathrm{a}=$ information not available, 1,2 -different brands of the same product type .

\subsection{Sensory Analysis}

Products were evaluated using a free-choice profiling method by five experienced flavor and sensory scientists (4 female, average age 40 ) in an informal focus group. The main sensory characteristics and attributes were discussed and recorded in the following order: Aroma, taste, texture, and mouthfeel.

\subsection{Volatile Analysis}

Cooked (or raw) samples were homogenized with water at a ratio of 1:2 and a slurry ( $3 \mathrm{~g})$ was transferred into headspace glass vials. An internal standard (4-methyl-1-pentanol) was added $(0.5 \mu \mathrm{g} / \mathrm{g})$.

Headspace analysis of samples was performed using solid-phase microextraction (SPME) and gas chromatography-mass spectrometry (GC-MS, Shimadzu QP-2010 Plus, Tokyo, Japan) and an auto-sampler (AOC-5000, Shimadzu, Rydalmere, NSW, Australia). Divinylbenzene/carboxen/polydimethylsiloxane SPME fibers ( $23^{\prime}$ gauge, $2 \mathrm{~cm}$, Agilent Technologies, Bellefonte, PA, USA) were used for volatile extraction at $40{ }^{\circ} \mathrm{C}$ for $60 \mathrm{~min}$ and desorbed in the splitless mode into the GC injector $\left(240^{\circ} \mathrm{C}\right.$ for $\left.5 \mathrm{~min}\right)$.

Compounds were separated on a Zebron-WAX capillary column (length $30 \mathrm{~m}$, ID $0.25 \mathrm{~mm}$, and thickness $0.50 \mu \mathrm{m}$, Phenomenex, Lane Cove West, NSW, Australia). The carrier gas was helium $(1.04 \mathrm{~mL} / \mathrm{min}$ flow rate). The initial column temperature was held 
at $35^{\circ} \mathrm{C}$ for $5 \mathrm{~min}$, then increased to $250{ }^{\circ} \mathrm{C}$ at $5{ }^{\circ} \mathrm{C} / \mathrm{min}$ and held for $5 \mathrm{~min}$. Detection of volatiles was performed in electron ionization mode (EI), $70 \mathrm{eV}$ over a mass range $\mathrm{m} / \mathrm{z}$ 40-250. Kovats retention indices (RI), EI mass spectral library matches, and, in most cases, reference chemicals (R) were used for identification. Except for natto, volatiles were only measured in the cooked samples as they are all typically eaten after grilling or thermal processing. The volatile data were semi-quantified based on the response against the internal standard (4-methyl-1-pentanol), normalized, and then multiplied by the final concentration of the internal standard, assuming a response factor equal to one for all the compounds and expressed as a concentration $(\mu \mathrm{g} / \mathrm{g})$.

\subsection{Extraction of Non-Volatile Metabolites}

Uncooked samples were homogenized using a hand blender (600 Watt, Braun, Germany) and mixed with 70\% methanol at the ratio of 1:2. Extraction was conducted using a TissueLyser (Qiagen Retsch MM300, Haan, Germany) for 15 min. Samples were then centrifuged (Model 1-15, Sigma Laborzentrifugen, Osterode am Harz, Germany) at 18,000 r.c.f. for $15 \mathrm{~min}$. The supernatant was collected, and the residue re-extracted under the same conditions. The supernatants were mixed and filtered using nylon filters (Phenex, $0.2 \mu \mathrm{m}$, Phenomenex, Lane Cove West, NSW, Australia).

\subsection{Identification of Metabolites Using Liquid Chromatography-Mass Spectrometry LC-MS}

Liquid chromatography analysis was performed using a Dionex chromatograph equipped with a pump, autosampler, column compartment and diode array detector (Ultimate 3000RS, Thermo Fisher Scientific, Scoresby, VIC, Australia). Chromatographic separation of compounds was performed on an Intrada Amino Acid column (length $150 \mathrm{~mm} \times$ I.D. $3 \mathrm{~mm}$; particle size $3 \mu \mathrm{m}$; Imtakt, Portland, OR, USA). The mobile phase consisted of acetonitrile/0.1\% formic acid (solvent A) and $100 \mathrm{mM}$ ammonium formate (solvent B). A constant flow rate of $0.6 \mathrm{~mL} / \mathrm{min}$ was used with a gradient elution program: $14 \%$ B (0 min), 100\% B (3 min), 100\% B (10 min), 14\% B (12.5 min), and 14\% B (15 min). The injection volume was $5 \mu \mathrm{L}$.

Accurate mass measurement of metabolites was conducted on a Q-Exactive ${ }^{\mathrm{TM}}$ Orbitrap LC-MS (Thermo Fisher Scientific) equipped with a heated electrospray ionization (H-ESI) source. The source conditions were as follows: Spray voltage (positive ion $3.9 \mathrm{kV}$ ), sheath gas 60 (arbitrary units), auxiliary gas 10 (arbitrary units) and sweep gas 1 (arbitrary units), capillary temp $350^{\circ} \mathrm{C}$, and auxiliary gas heating temp $400^{\circ} \mathrm{C}$. Mass spectra were acquired in data-dependent workflow in positive and recorded over the mass range of $\mathrm{m} / \mathrm{z}$ 70-500 (Xcalibur ${ }^{\mathrm{TM}} 4.3$, Thermo Fisher Scientific).

\subsection{Identification of Metabolites Using Compound Discoverer Software}

Compound Discoverer Ver 3.1 (Thermo Fisher Scientific) was used for identification of untargeted metabolites using a standard workflow template for food science. ACToR (Aggregated Computational Toxicology Resource, U.S. Environmental Protection Agency, USA); FDA UNII-NLM (U.S. Food and Drug Administration, MD, USA); FooDB (The Food Database, The Metabolomics Innovation Centre, Edmonton, Alberta, Canada); and the Peptides databases were selected for identification of compounds. Only compounds with a high mzCloud match (>60 with majority $>80)$ were assigned an identity and used in subsequent analyses.

\subsection{Statistical Analysis}

Initial data manipulation and analysis was conducted using Microsoft Excel and $\mathrm{R}$ version 4.0.1 using the tidyverse package [39]. Normalized and semi-quantified volatile data were subjected to MANOVA analysis using GenStat 19th (VSN-International, Hemel Hempstead, UK) statistical package. 


\section{Results}

\subsection{General Description of Main Sensory Attributes of Products}

Both raw and cooked natto had similar very strong odors, described as coffee, caramel, meaty, and, for some samples, ammonia-like (Table 2). It should be noted that natto is most often consumed cold or at room temperature [40]. The fried tempeh had fermented cider, beany and meaty aroma qualities, and a sour and umami taste. Fried tofu had beany, baked, and mild nutty flavors and was slightly bitter and quite beany in taste. The meat substitutes had variable flavor characteristics as expected from the differences in their listed ingredients. Many had meaty and herb-like flavors as well as grainy, acidic, and salty characteristics.

\subsection{Volatile Analysis}

A total of 98 volatiles were identified across the meat, meat substitutes, and fermented plant food products using the SPME GC-MS method (Table S1). Obvious qualitative and quantitative differences between the volatile profiles of meat and plant-based products were observed (Figure 1). Overall, the traditional plant-based products (natto, tempeh, and tofu) had a higher concentration of total volatiles compared to meat and meat substitute products. The concentration of total volatiles in natto and tempeh was approximately 10 times higher than in the meat samples. The volatile profile of the natto was dominated by alkylpyrazines and ketones, whereas the tempeh was dominated by alcohols and aldehydes. The cooked tofu had a higher concentration of most volatile classes compared to meat, especially alcohols, furans, and organic acids (acetic acids). The concentration of volatiles in the meat substitutes was generally higher than in meat, with a relatively high concentration of alcohols (mainly ethanol), furans (mainly 2-pentylfuran), and ketones, mainly 2,3butanedione (diacetyl) and 3-hydroxy-2-butanone (acetoin). It should be noted that no consideration of the odor quality or differences in odor activity of volatile compounds was considered in this study.

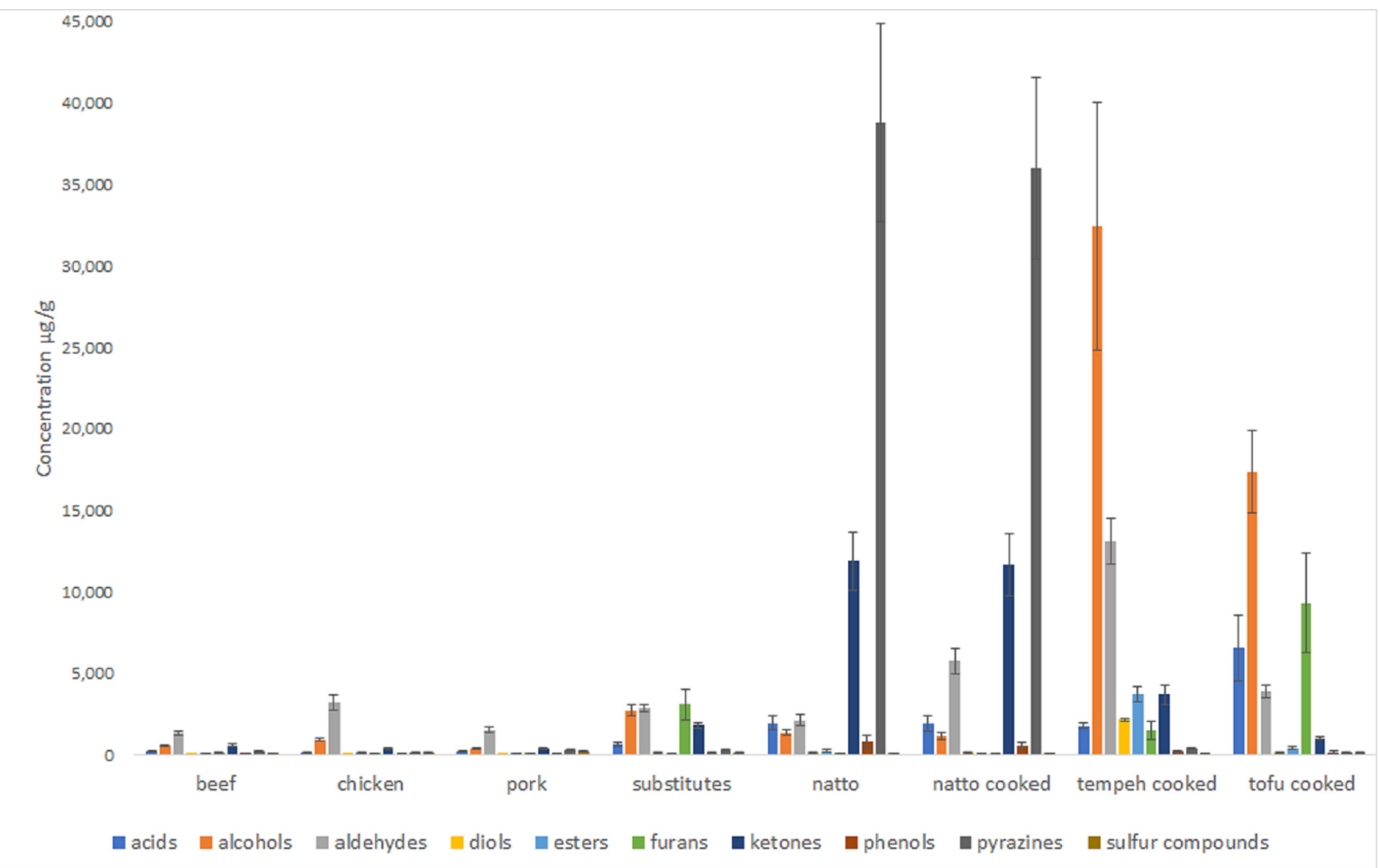

Figure 1. Volatile profile of meat, meat substitutes, natto, tempeh, and tofu according to chemical class. The concentration of each compound is normalized and calculated based on the internal standard (4-methyl-1-pentanol) assuming a response factor equal to one for all compounds. 
Table 2. Sensory descriptors of meat substitutes and traditional plant-based high-protein food products $(n=5)$.

\begin{tabular}{|c|c|c|c|c|c|c|c|c|}
\hline Product & Type & Brand & $\begin{array}{c}\text { Main } \\
\text { Ingredient }\end{array}$ & Aroma & Flavor/Taste & Texture & Appearance & Mouthfeel \\
\hline MS1 & burger & cooked & black beans & $\begin{array}{l}\text { beany, slight smoky, grainy, } \\
\text { fresh vegetables, not } \\
\text { much aroma }\end{array}$ & $\begin{array}{l}\text { spicy, pleasant, not like beef, } \\
\text { salty, beany, lentils, sweet, } \\
\text { grainy, beetroot }\end{array}$ & $\begin{array}{l}\text { firm, chewy, hard particles, } \\
\text { stay intact upon cutting, soft, } \\
\text { crumbly particles, grainy } \\
\text { particles, firm on plate, falls } \\
\text { in pieces in mouth }\end{array}$ & $\begin{array}{c}\text { red/purple and black } \\
\text { particles, nice browning, } \\
\text { visible grains, dark, pink, } \\
\text { layered pieces (beans pieces) }\end{array}$ & $\begin{array}{l}\text { not fatty, dry, } \\
\text { not juicy }\end{array}$ \\
\hline MS2 & burger & cooked & vegetables & $\begin{array}{l}\text { oregano, strong rosemary, } \\
\text { herbs, not meat-like, spicy, } \\
\text { beany, strong, curry, mustard }\end{array}$ & $\begin{array}{c}\text { salty, sweet, herbs, like } \\
\text { stuffing, not unpleasant, } \\
\text { starchy, MSG, sweet, taste like } \\
\text { mix of vegetables }\end{array}$ & $\begin{array}{l}\text { soft, chewy, cohesive, sticky, } \\
\text { stay intact upon cutting, soft, } \\
\text { oily, residue in mouth, } \\
\text { tooth packing }\end{array}$ & $\begin{array}{c}\text { yellow/orange/brown/grainy, } \\
\text { visible green and carrot } \\
\text { pieces, veg chunks like in } \\
\text { veg burgers }\end{array}$ & soft, oily \\
\hline MS3 & burger & cooked & brown rice & $\begin{array}{l}\text { not meat-like, brown rice } \\
\text { smell, guaiacol, cooked } \\
\text { grains, spicy, smoky, beany, } \\
\text { rosemary, cooked vegetables, } \\
\text { very grainy, spices } \\
\text { (pepper), seeds }\end{array}$ & $\begin{array}{l}\text { salty, rice flavor, very strong } \\
\text { grainy taste, acidic, cereal, } \\
\text { aftertaste not beefy, very salty, } \\
\text { not great flavor, starchy, } \\
\text { herbal, peppery, rye }\end{array}$ & $\begin{array}{l}\text { medium firm, chewy, stay } \\
\text { intact upon cutting, soft, } \\
\text { grainy particles }\end{array}$ & $\begin{array}{l}\text { visible rice grains, grainy, } \\
\text { brown color, dark, flaky }\end{array}$ & crumbly \\
\hline MS4 & burger & cooked & soy protein & $\begin{array}{l}\text { herbal, mild beefy, spicy, } \\
\text { overpowering, mushroom }\end{array}$ & $\begin{array}{l}\text { bland, spicy, starchy, beany } \\
\text { aftertaste, parsley, spicy } \\
\text { paprika-not really that nice, } \\
\text { herbal, spices, a bit salty, } \\
\text { grainy, very spicy }\end{array}$ & $\begin{array}{l}\text { compact, cohesive, chewy, } \\
\text { soft, sticky, dense, soft, not } \\
\text { too dry, no } \\
\text { particles-processed, first bite } \\
\text { is nice then too much } \\
\text { processing needed }\end{array}$ & $\begin{array}{l}\text { red color, looks dry, thick and } \\
\text { round edges, nice browning, } \\
\text { red beef color, like burger, } \\
\text { thick dense raw meat } \\
\text { appearance }\end{array}$ & $\begin{array}{c}\text { not fatty, } \\
\text { not juicy, } \\
\text { sucks saliva }\end{array}$ \\
\hline MS5 & burger & cooked & pea protein & $\begin{array}{l}\text { meaty, slight-strong smoky, } \\
\text { tomato, onion, beefy, not } \\
\text { pleasant, strong off, acidic, } \\
\text { artificial, smells like meat }\end{array}$ & $\begin{array}{l}\text { slightly salty, umami, meaty, } \\
\text { mushroom, spicy, off, strong } \\
\text { aftertaste, smoky, cat food, } \\
\text { grainy, aftertaste }\end{array}$ & $\begin{array}{l}\text { soft, meat-like texture, looks } \\
\text { good, looks like meat, texture } \\
\text { like a burger, tender }\end{array}$ & $\begin{array}{l}\text { homogenous but can see } \\
\text { particles, good browning, } \\
\text { good brown color, } \\
\text { meaty appearance }\end{array}$ & $\begin{array}{l}\text { juicy, oily, } \\
\text { not dry }\end{array}$ \\
\hline MS6 & mince & cooked & mycoprotein & $\begin{array}{l}\text { strong acidic, grainy, acetic } \\
\text { acid, mild mushroom, starchy, } \\
\text { cardboard, strong grainy, } \\
\text { wet paper }\end{array}$ & $\begin{array}{l}\text { not nice taste, very bland, } \\
\text { strong acidic, weird taste, not } \\
\text { meaty, cardboard, cereals, } \\
\text { some bitterness, not } \\
\text { salty, acidic }\end{array}$ & $\begin{array}{l}\text { powdery, sticky, firm bite, } \\
\text { moist, resistant to chew, } \\
\text { chewy, crumbly, soft, very } \\
\text { small particles }\end{array}$ & $\begin{array}{l}\text { looks like mince, good brown } \\
\text { color, meat color }\end{array}$ & $\begin{array}{l}\text { dry, crumbly, } \\
\text { not too dry }\end{array}$ \\
\hline MS7 & mince & cooked & soy protein & $\begin{array}{l}\text { vomit, cooked grain smell, } \\
\text { not meat like, off, oily, starchy, } \\
\text { revolting aroma, cardboard }\end{array}$ & $\begin{array}{l}\text { salty, spicy, off, vomit, } \\
\text { chemical/artificial, very } \\
\text { bread-like aftertaste }\end{array}$ & $\begin{array}{l}\text { good texture, springy pieces, } \\
\text { holds tongue well, chewy, } \\
\text { pasty, bouncy }\end{array}$ & looks like mince, brown & soft \\
\hline
\end{tabular}


Table 2. Cont.

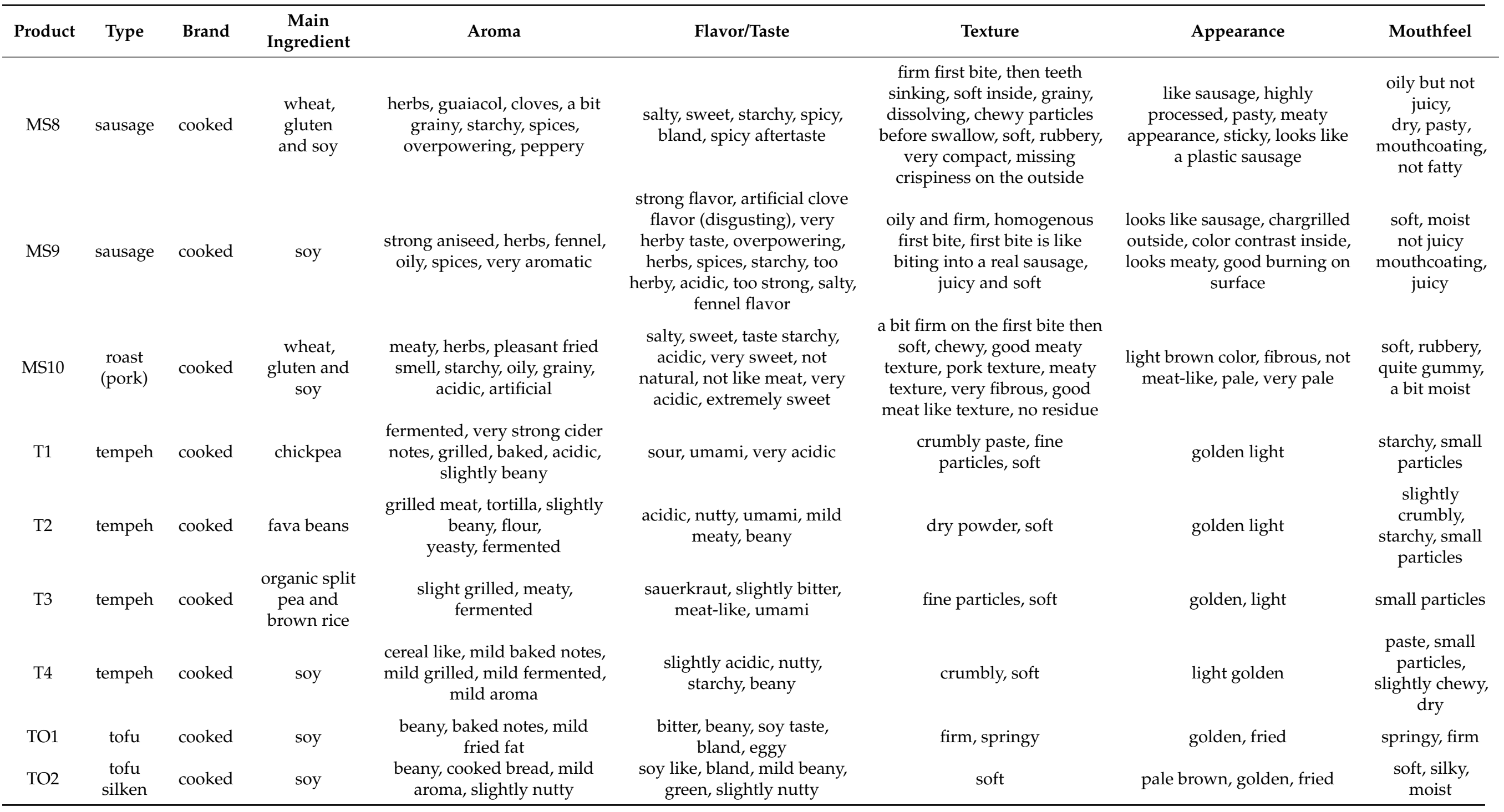


Table 2. Cont.

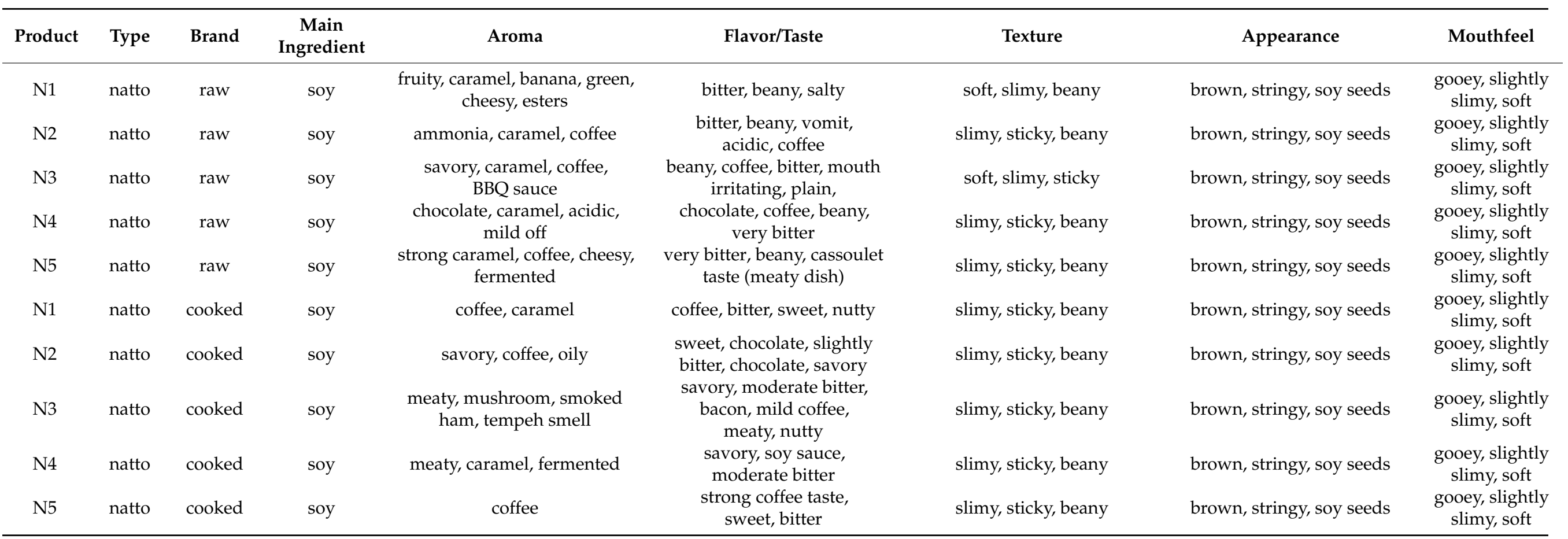

MS $=$ Meat Substitute, $\mathrm{T}=$ Tempeh, $\mathrm{TO}=$ Tofu, $\mathrm{N}=$ Natto, $\mathrm{BM}=$ Beef Mince, BS $=$ Beef Steak, $\mathrm{CT}=$ Chicken Thigh, $\mathrm{CB}=\mathrm{Chicken}$ Breast, $\mathrm{PL}=$ Pork Loin, $\mathrm{PS}=\mathrm{Pork}$ Sirloin, $\mathrm{PC}=$ pork cutlet 
Chicken had a higher concentration of aldehydes and alcohols relative to beef and pork. Natto had high concentrations of 2,3-dimethylpyrazine, trimethylpyrazine, tetramethyl pyrazine, 3-ethyl-2-5-dimethylpyrazine, 2,3,5-trimethyl-6-ethylpyrazine, 2,3-butanedione, 3-hydroxy-2-butanone (acetoin), 2,4-(E,E)-hexadienal, and isovaleric acid.

Ethanol, 2-phenylethylalcohol, (E)-2-butenal, 3-hydroxy-2-butanone, acetaldehyde, $(E, E)$-2,4-decadienal, and 2-pentyfuran were the most concentrated volatiles in cooked tempeh headspace (Table S1). These compounds were reported previously as important flavor volatiles produced during fermentation of soybean using Rhizopus oligosporus [41]. A series of ethyl esters (ethyl acetate, ethyl propionate, ethyl-2-methyl butanoate, ethyl3-methyl butanoate, ethyl hexanoate, ethyl ethanoate and ethyl octanoate, and methyl benzoate were highly concentrated in tempeh, when compared to other products. Both raw and cooked tempeh are described as having strong fermented flavor attributes. Grilled meat flavor was also described as an attribute (Table 2) in the fried tempeh. Tempeh had a relatively high concentration of total pyrazines, dominated mainly by trimethylpyrazine and 3-ethyl-2,5-dimethylpyrazine.

Quantitatively, the main volatiles identified in tofu were 1-octen-3-ol, 2-pentylfuran, acetic acid, 1-hexanol, and hexanal.

Meat substitutes had a higher concentration of total volatiles, when compared to beef, chicken, and pork. Overall, 2-pentylfuran and d-limonene were the most abundant volatiles in the meat substitutes. In other respects, the plant-based products had similar volatile profiles to the meat samples (Table S1).

Chicken had the highest average concentration of total volatiles among meat samples, followed by pork and beef, which is in general agreement with previous studies [42,43]. The fat derived volatiles, hexanal, 1-octen-3-ol, nonanal, and pentanal, were dominant in chicken. A similar flavor profile of chicken was reported by Schindler et al. [42]. Hexanal, benzaldehyde, 1-nonanol, 3-hydroxy-2-butanone, and 2-methylbutanal were the most concentrated volatiles in beef [44], while hexanal, nonanal, octane, carbon disulphide, and 1-octen-3-ol were highest in pork, which is mostly in agreement with previously published data [45].

\subsection{Non-Volatile Metabolites}

A total of 150 compounds (with an mzCloud match score of $>60$ ) were identified by the Compound Discoverer software: 30 free amino acids, 45 dipeptides, 25 tripeptides, 5 tetrapeptides, 11 nucleotides, 5 flavonoids, 2 pyrazines, and other unclassified compounds were identified in meat and plant-based foods (Table S2). As expected, the muscle meat products were abundant in the nitrogenous compounds L-carnosine, L-carnitine, acetyl-L-carnitine, and creatine (Figure 2a,b). Chicken and beef had the highest concentration of creatine, followed by L-carnitine and acetyl-L-carnitine. Betaine (trimethylglycine), choline, and hypoxanthine were also found in high concentrations in meat. Glutamic acid, aspartic acid, and glutamine (Figure 2c) were also highly abundant in beef, chicken, and pork and these free amino acids are known to directly contribute to the typical taste of meat [3]. When free amino acids (and other non-volatile substrates) on the surface of meat (or meat analogues and other high-protein foods) encounter typical grill temperatures they can participate in Maillard and Strecker reactions to form desirable meaty and grilled flavor volatiles $[3,20]$.

The traditional fermented products natto and tempeh were abundant in free amino acids and dipeptides. The free amino acids tyrosine, methionine, leucine, serine and glycine were the most concentrated in natto. Tempeh showed high concentration of glutamic acid and aspartic acid and the highest concentration of $\gamma$-aminobutyric acid (GABA). The glutamyl-dipeptides, $\gamma$-Glu-Leu, and $\gamma$-Glu-Glu were both abundant in natto. Many of the di- and tri-peptides were detected in natto and/or in tempeh including Val-Asp, Pro-Thr, Leu-Leu, Val-Met, Val-Pro, Pro-Met, Gly-Phe, Ala-Tyr, Thr-Tyr, ValGlu, Gln-Trp, Glu-Pro, Ala-Pro, Gln-Tyr, Val-Asn, Pro-Gln, Gln-His, Gly-Lys, Val-His and Val-Pro-Leu, Phe-Tyr, Thr-Pro, Leu-Gln, L-Arg-L-Ala, Gly-Leu-Pro, Ala-Glu-Leu, and 
Glu-Ala-Pro. Four $\gamma$-glutamyl peptides: $\gamma$-Glu-Leu, $\gamma$-Glu-Glu, $\gamma$-Glu-Cys, and $\gamma$-GluCys-Gly (glutathione) were identified in meat and some plant-based products (Figure 2c). $\gamma$-Glu-Leu was predominantly found in natto, some meat substitutes, tempeh, and in low concentration in pork cutlets and chicken thighs. $\gamma$-Glu-Glu was present in meat substitutes, natto, tempeh, and chicken samples. Glutathione was found in all the beef, chicken, and pork samples, while the glutathione precursor, $\gamma$-Glu-Cys, was only identified in chicken and pork samples.
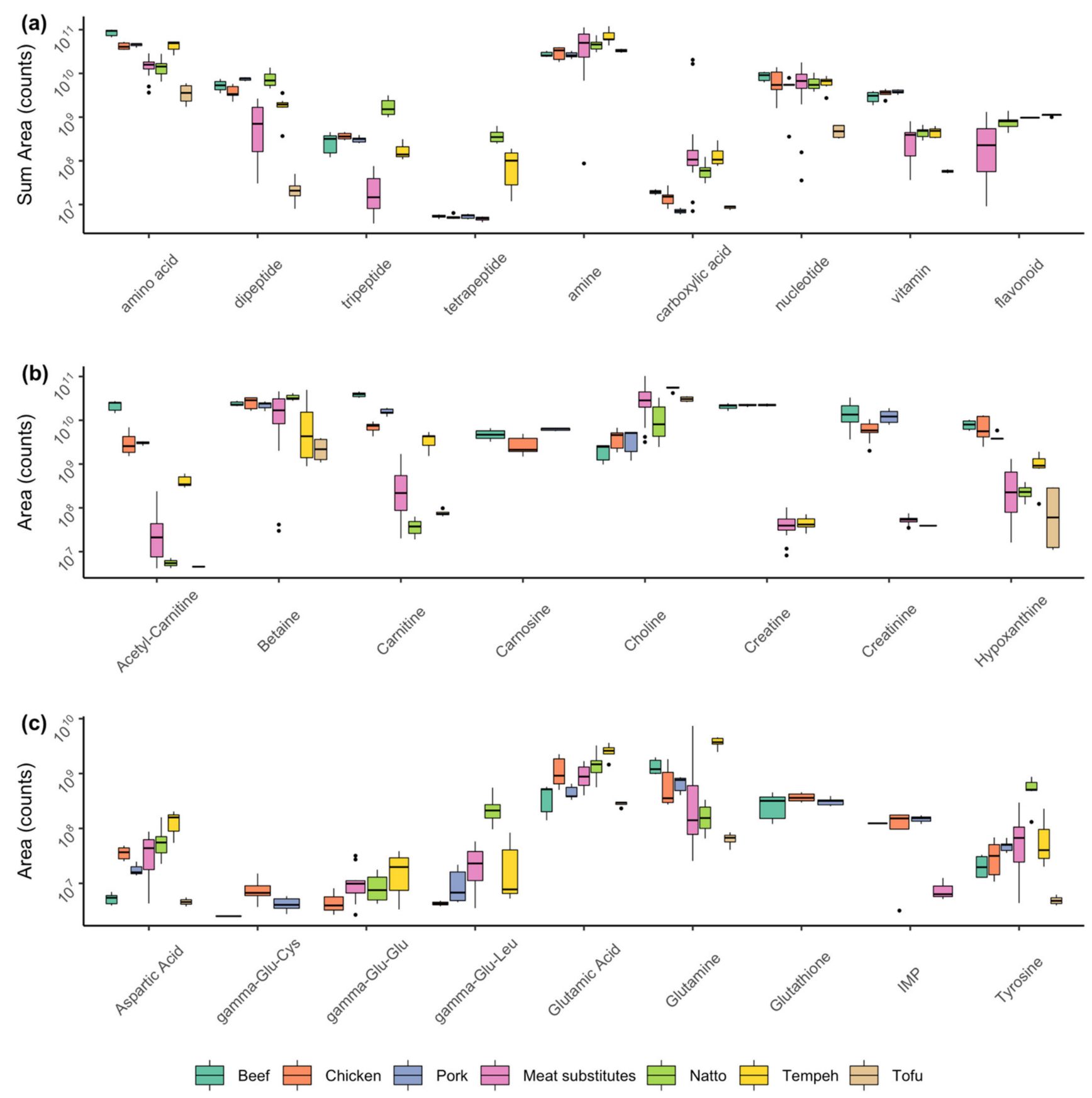

Figure 2. Non-volatile profile of meat, meat substitutes, natto, tempeh, and tofu. Box plots of: (a) All compounds from the major compound classes were summed, each sample was classified as either beef (green), chicken (orange), pork (blue), meat substitute (pink), natto (light green), tempeh (yellow), or tofu (beige); (b) the dominant amines in each sample group; (c) the dominant amino acids, di-, and tri-peptides; IMP is inosine 5'-monophosphate. Box plots show the median, 1 st and 3rd quartiles, minimum and maximum values and the dots represent the outliers. 


\section{Discussion}

Undesirable flavors of tofu characterized as beany, grassy, and bitter are associated with oxidation of polyunsaturated (PUFA) lipids by lipoxygenases (LOX) present in soybeans $[37,46,47]$. Soybeans are known to contain up to $50 \%$ of linoleic acid and up to $11 \%$ of linolenic acids-both PUFAs are susceptible to oxidation and associated with the formation of undesirable flavors in soy products [47]. The same oxidation of lipids may lead to the formation of the beany flavor of tempeh [41]. 1-octen-3-ol, 2-pentylfuran, 1-hexanol, and hexanal were reported previously as the main volatiles in tofu contributing to green and beany notes in soymilk. These volatiles presented $55 \%$ of total volatiles in tofu and are formed during degradation of polyunsaturated fatty acids [36]. Formation of esters have been linked with the growth of yeast and/or fungi in tempeh fermentation, leading to modified sensory properties of the final product [48].

It is well known that volatiles differ widely in their odor-activity value, and the highest odor-impact volatiles typically constitute only a small fraction of the total volatiles and are often present at very low concentration [49]. For example, the odor threshold concentration of alcohols are typically orders of magnitude higher than for aldehydes.

Pyrazines are important contributors to natto typical flavors and are already present in abundance in the raw natto and are related to strong toast/nut-like odor [32,50]. 2,5dimethylpyrazine and tetramethylpyrazine are also formed during solid state fermentation of soybean using Bacillus subtilis [51] Most of these pyrazines have been reported previously in cooked meat aroma [3,52-54], with the notable exception of tetramethylpyrazine. Trimethylpyrazine and 3-ethyl-2,5-dimethylpyrazine are also important contributors to the roast or grilled beef aroma $[3,5,55]$.

The meat substitutes examined in our study were produced from a variety of main protein ingredients (Table 1), some with the addition of spices and other ingredients, leading to increased complexity of the volatile profiles. Notably, higher concentration of 2-pentylfuran in comparison to meat samples may indicate the presence of soy and/or other legumes. The monoterpene d-limonene is present in many herbs and spices and may be considered a marker of the addition of dried herbs [56].

Volatile aldehydes including hexanal, heptanal, octanal, and nonanal are formed during oxidation of fat and are abundant in beef, chicken, and pork, and make an important contribution to cooked meat flavor [3,42,43]. An elevated concentration of aldehydes (particularly hexanal) is often used as an indicator of freshness/flavor deterioration of meat $[44,57]$. Hexanal, 1-octen-3-ol, nonanal, and pentanal, were dominant in chicken. These volatiles are formed through the thermal oxidation of unsaturated fatty acids such as linoleic acid present in neutral lipid. Chicken fat is relatively high in linoleic acid [58].

Non-volatile analytes are important flavor compounds and flavor precursors, and their impact on the flavor profile depends on cooking conditions. In cooked meat, free amino acids, peptides, sugars, nucleotides, and thiamine are the main flavor precursors [14]. L-carnitine and creatine are considered as bioactive components of meat, playing a role in muscle energy metabolism $[59,60]$. Betaine has been shown to contribute to the umami flavor of seafoods [61]; choline is an essential nutrient involved in the biosynthesis of membrane lipids [62]. Hypoxanthine is formed from purine degradation and enhances meat taste [63]. Glutamic acid, aspartic acid, and glutamine contribute to meaty and umami flavor characteristics of meat. Both cysteine and glutathione are important precursors for the Maillard reaction products observed in meat flavor. Glutathione and $\gamma$-glutamyl peptides are also recognized as kokumi-imparting molecules reported previously in edible beans and matured Gouda cheese $[47,64]$ which may have a role in flavor modification and improving the mouthfeel, thick flavor, and enhancing the intensity of continuity [17].

Free amino acids and dipeptides are important flavor precursors in foods. In fermented foods such as tempeh or natto, free amino acids and peptides are main contributors to its characteristic flavor $[65,66]$. Enzymatic hydrolysis of proteins during fermentation can lead to bitter taste related to the formation of a high concentration of hydrophobic bitter peptides and bitter free amino acids (leucine, valine, isoleucine, arginine, phenylala- 
nine, tyrosine, and tryptophan) [67]. However, some of the peptides formed contribute to desirable umami taste, especially glutamyl dipeptides [28,66]. Kim et al. [40] reported that the fermentation of natto leads to an increase of all free amino acids with the greatest increase of glutamic acids, lysine, tyrosine, and phenylalanine. Increased formation of free amino acids and dipeptides has also been reported to increase meaty and umami flavor of fermented soybean [65]. Serine and glycine contribute to an increased perception of umami flavor of inosine monophosphate (IMP) in soy sauce [68]. The glutamyl-dipeptides, $\gamma$-Glu-Leu, and $\gamma$-Glu-Glu were shown to impart kokumi sensations [64]. Aspartic acid and glutamic acids are both known to contribute to kokumi and umami flavor character $[28,66]$.

Many di- and tri-peptides have been reported in literature to have bioactive properties. For instance, Val-Asp, Pro-Thr, Leu-Leu, Val-Met, Val-Pro, Pro-Met, Gly-Phe, Ala-Tyr, Thr-Tyr, Val-Glu, Gln-Trp, Glu-Pro, Ala-Pro, Gln-Tyr, Val-Asn, Pro-Gln, Gln-His, Gly-Lys, Val-His, and Val-Pro-Leu present in natto and the majority present in tempeh may act as anti-diabetic agents as they were reported to have dipeptidyl peptidase IV inhibition properties [69,70]. Furthermore, the peptides Phe-Tyr, Thr-Pro, Leu-Gln, L-Arg-L-Ala, Gly-Leu-Pro, Ala-Glu-Leu, and Glu-Ala-Pro, abundant in natto and in tempeh, possess angiotensin-converting enzyme inhibition (ACE) properties and may help in reducing hypertension $[69,70]$. GABA, found in tempeh, is produced primarily through decarboxylation of glutamic acid and is known to possess antioxygenic and hypotensive effects in rats. It is also an inhibitory neurotransmitter and is used to relieve symptoms such as sleeplessness, depression, and autonomic disorder [27].

The meat substitutes varied in the composition of free amino acids, peptides, and nucleotides compared to meat and traditional plant-based foods. This is likely to be due to the variety of ingredients used to formulate the products. Food manufacturers may add mixtures of free amino acids, nucleotides, and sugars, yeast extracts, protein hydrolysates, and fermented ingredients to create meat-like flavors. Glutamic acid, aspartic acid, monosodium glutamate, and $5^{\prime}$ ribonucleotides are often added to non-meat products to enhance savoury, meaty, and umami flavors [28,71].

\section{Conclusions}

The flavor profiles of natto, tempeh, and tofu were very different to the flavor profiles of meat and meat substitutes. While the volatile profile of cooked meat is predominately influenced by aldehydes and alcohols, traditional plant-based foods show a more diverse volatile profile, highly influenced by the fermentation microorganisms and/or other processing method, as in the case of tofu. Natto is a very rich source of potentially bioactive peptides and taste-active compounds when compared to meat. With further processing (heating, drying), natto (and isolated fractions) could be added back into plant-based meat products to increase umami and kokumi flavors as well as improve nutritional profiles.

Supplementary Materials: The following are available online at https:/ /www.mdpi.com/article/10 $.3390 /$ foods 10040801/s1, Table S1: Statistical analysis of the volatile metabolites measured by SPME GC-MS, Table S2: Statistical analysis of the non-volatile metabolites measured by LC-MS.

Author Contributions: Conceptualization, K.K. and D.F.; methodology, U.P., K.K., and D.F.; validation, K.K., U.P., M.T., and D.F.; formal analysis, K.K., M.T., and D.F.; investigation, K.K. and U.P.; resources, U.P.; data curation, K.K. and U.P.; writing—original draft preparation, K.K.; writingreview and editing, K.K., M.T., and D.F.; visualization, K.K. and M.T.; supervision, D.F. and M.T.; project administration, D.F.; funding acquisition, D.F. All authors have read and agreed to the published version of the manuscript.

Funding: This research was funded by CSIRO Precision Health Future Science Platform.

Acknowledgments: The authors would like to thank Anita Sikes and Adil Malik from CSIRO Agriculture and Food for critical review of the manuscript.

Conflicts of Interest: The authors declare no conflict of interest. 


\section{References}

1. Ritchie, H.; Reay, D.S.; Higgins, P. Potential of Meat Substitutes for Climate Change Mitigation and Improved Human Health in High-Income Markets. Front. Sustain. Food Syst. 2018, 2, 16. [CrossRef]

2. Faucitano, L.; Martelli, G.; Nannoni, E.; Widowski, T. Chapter 21-Fundamentals of Animal Welfare in Meat Animals and Consumer Attitudes to Animal Welfare A2-Purslow. In New Aspects of Meat Quality; Peter, P., Ed.; Woodhead Publishing: Sawston, UK, 2017; pp. 537-568. [CrossRef]

3. Frank, D.; Ball, A.; Hughes, J.; Krishnamurthy, R.; Piyasiri, U.; Stark, J.; Watkins, P.; Warner, R. Sensory and Flavor Chemistry Characteristics of Australian Beef: Influence of Intramuscular Fat, Feed, and Breed. J. Agric. Food Chem. 2016, 64, 4299-4311. [CrossRef] [PubMed]

4. Schlichtherle-Cerny, H.; Grosch, W. Evaluation of taste compounds of stewed beef juice. Z. Fur Lebensm. Unters. Und Forsch. A-Food Res. Technol. 1998, 207, 369-376. [CrossRef]

5. Cerny, C.; Grosch, W. Quantification of character-impact odor compounds of roasted beef. Z. Fur Lebensm. Unters. Und Forsch. 1993, 196, 417-422. [CrossRef]

6. Aliani, M.; Farmer, L.J. Precursors of Chicken Flavor. II. Identification of Key Flavor Precursors Using Sensory Methods. J. Agric. Food Chem. 2005, 53, 6455-6462. [CrossRef]

7. Aliani, M.; Farmer, L.J. Precursors of Chicken Flavor. I. Determination of Some Flavor Precursors in Chicken Muscle. J. Agric. Food Chem. 2005, 53, 6067-6072. [CrossRef] [PubMed]

8. Farmer, L.J.; Hagan, T.D.J.; Paraskevas, O. Role of Selected Precursors in Meat Flavor Formation. In Quality Attributes of Muscle Foods; Xiong, Y.L., Chi-Tang, H., Shahidi, F., Eds.; Springer: Boston, MA, USA, 1999; pp. 159-172. [CrossRef]

9. Farmer, L.J.; Mottram, D.S.; Whitfield, F.B. Volatile compounds produced in Maillard reactions involving cysteine, ribose and phospholipid. J. Sci. Food Agric. 1989, 49, 347-368. [CrossRef]

10. Rodbotten, M.; Kubberod, E.; Lea, P.; Ueland, O. A sensory map of the meat universe. Sensory profile of meat from 15 species. Meat Sci. 2004, 68, 137-144. [CrossRef]

11. Pereira, P.C.; Vicente, F. Chapter 18-Meat Nutritive Value and Human Health A2-Purslow. In New Aspects of Meat Quality; Peter, P., Ed.; Woodhead Publishing: Sawston, UK, 2017; pp. 465-477. [CrossRef]

12. Frank, D.; Oytam, Y.; Hughes, J. Chapter 27-Sensory Perceptions and New Consumer Attitudes to Meat A2-Purslow. In New Aspects of Meat Quality; Peter, P., Ed.; Woodhead Publishing: Sawston, UK, 2017; pp. 667-698. [CrossRef]

13. Zamora, R.; Navarro, J.L.; Aguilar, I.; Hidalgo, F.J. Lipid-derived aldehyde degradation under thermal conditions. Food Chem. 2015, 174, 89-96. [CrossRef] [PubMed]

14. Mottram, D.S. Flavour formation in meat and meat products: A review. Food Chem. 1998, 62, 415-424. [CrossRef]

15. Hartley, I.E.; Liem, D.G.; Keast, R. Umami as an 'Alimentary' Taste. A New Perspective on Taste Classification. Nutrients 2019, 11, 182. [CrossRef]

16. Kurihara, K. Umami the Fifth Basic Taste: History of Studies on Receptor Mechanisms and Role as a Food Flavor. Biomed. Res. Int. 2015, 189402. [CrossRef]

17. Kuroda, M.; Miyamura, N. Mechanism of the perception of "kokumi" substances and the sensory characteristics of the "kokumi" peptide, $\gamma$-Glu-Val-Gly. Flavour 2015, 4, 11. [CrossRef]

18. Dunkel, A.; Köster, J.; Hofmann, T. Molecular and Sensory Characterization of $\gamma$-Glutamyl Peptides as Key Contributors to the Kokumi Taste of Edible Beans (Phaseolus vulgaris L.). J. Agric. Food Chem. 2007, 55, 6712-6719. [CrossRef]

19. Frank, D.; Joo, S.-T.; Warner, R. Consumer Acceptability of Intramuscular Fat. Korean J. Food Sci. Anim. Resour. 2016, 36, 699-708. [CrossRef]

20. Frank, D.; Kaczmarska, K.; Paterson, J.; Piyasiri, U.; Warner, R. Effect of marbling on volatile generation, oral breakdown and in mouth flavor release of grilled beef. Meat Sci. 2017, 133, 61-68. [CrossRef] [PubMed]

21. Oostindjer, M.; Alexander, J.; Amdam, G.V.; Andersen, G.; Bryan, N.S.; Chen, D.; Corpet, D.E.; De Smet, S.; Dragsted, L.O.; Haug, A.; et al. The role of red and processed meat in colorectal cancer development: A perspective. Meat Sci. 2014, 97, 583-596. [CrossRef]

22. Douglas, S.M.; Lasley, T.R.; Leidy, H.J. Consuming Beef vs. Soy Protein Has Little Effect on Appetite, Satiety, and Food Intake in Healthy Adults. J. Nutr. 2015, 145, 1010-1016. [CrossRef] [PubMed]

23. Godfray, H.C.J.; Aveyard, P.; Garnett, T.; Hall, J.W.; Key, T.J.; Lorimer, J.; Pierrehumbert, R.T.; Scarborough, P.; Springmann, M.; Jebb, S.A. Meat consumption, health, and the environment. Science 2018, 361, 243. [CrossRef] [PubMed]

24. Delimaris, I. Adverse Effects Associated with Protein Intake above the Recommended Dietary Allowance for Adults. ISRN Nutr. 2013, 2013, 126929. [CrossRef] [PubMed]

25. Polanowska, K.; Grygier, A.; Kuligowski, M.; Rudzinska, M.; Nowak, J. Effect of tempe fermentation by three different strains of Rhizopus oligosporus on nutritional characteristics of faba beans. LWT Food Sci Technol. 2020, 122, 109024. [CrossRef]

26. Wolkers-Rooijackers, J.C.M.; Endika, M.F.; Smid, E.J. Enhancing vitamin B-12 in lupin tempeh by in situ fortification. LWT Food Sci. Technol. 2018, 96, 513-518. [CrossRef]

27. Xiao, C.W. 22-Functional soy products. In Functional Foods, 2nd ed.; Saarela, M., Ed.; Woodhead Publishing: Sawston, UK, 2011; pp. 534-556. [CrossRef]

28. Charve, J.; Manganiello, S.; Glabasnia, A. Analysis of Umami Taste Compounds in a Fermented Corn Sauce by Means of Sensory-Guided Fractionation. J. Agric. Food Chem. 2018, 66, 1863-1871. [CrossRef] 
29. Iwaniak, A.; Minkiewicz, P.; Darewicz, M.; Sieniawski, K.; Starowicz, P. BIOPEP database of sensory peptides and amino acids. Food Res. Int. 2016, 85, 155-161. [CrossRef] [PubMed]

30. Zhang, Y.; Venkitasamy, C.; Pan, Z.; Liu, W.; Zhao, L. Novel umami ingredients: Umami peptides and their taste. J. Food Sci. 2017, 82, 16-23. [CrossRef]

31. Nout, M.J.R.; Kiers, J.L. Tempe fermentation, innovation and functionality: Update into the third millenium. J. Appl. Microbiol. 2005, 98, 789-805. [CrossRef] [PubMed]

32. Liu, Y.; Su, H.; Song, H.-L.J.F.A.M. Comparison of Four Extraction Methods, SPME, DHS, SAFE, Versus SDE, for the Analysis of Flavor Compounds in Natto. Food Anal. Methods 2018, 11, 343-354. [CrossRef]

33. Yoshie-Stark, Y.; Wäsche, A. Characteristics of crude lipoxygenase from commercially de-oiled lupin flakes for different types of lupins (Lupinus albus, Lupinus angustifolius). Food Chem. 2004, 88, 287-292. [CrossRef]

34. Wang, W.; Zhou, X.; Liu, Y. Characterization and evaluation of umami taste: A review. TRAC Trends Anal. Chem. 2020, 127, 115876. [CrossRef]

35. Kumar, P.; Chatli, M.K.; Mehta, N.; Singh, P.; Malav, O.P.; Verma, A.K. Meat analogues: Health promising sustainable meat substitutes. Crit. Rev. Food Sci. Nutr. 2017, 57, 923-932. [CrossRef]

36. Wang, Y.; Yang, X.; Li, L. A new style of fermented tofu by Lactobacillus casei combined with salt coagulant. 3 Biotech 2020, 10, 81. [CrossRef]

37. Kaczmarska, K.T.; Chandra-Hioe, M.V.; Frank, D.; Arcot, J. Aroma characteristics of lupin and soybean after germination and effect of fermentation on lupin aroma. LWT Food Sci. Technol. 2018, 87, 225-233. [CrossRef]

38. Kaczmarska, K.T.; Chandra-Hioe, M.V.; Zabaras, D.; Frank, D.; Arcot, J. Effect of Germination and Fermentation on Carbohydrate Composition of Australian Sweet Lupin and Soybean Seeds and Flours. J. Agric. Food Chem. 2017, 65, 10064-10073. [CrossRef] [PubMed]

39. Wickham, H.; Averick, M.; Bryan, J.; Chang, W.; McGowan, L.D.A.; Francois, R.; Grolemund, G.; Hayes, A.; Henry, L.; Hester, J.; et al. Welcome to Tidyverse. J. Open Source Softw. 2019, 4, 1686. [CrossRef]

40. Kim, B.-R.; Han, Y.-B.; Park, C.-H. Changes of free amino acids during the Natto fermentation used by Bacillus subtilis S.N.U 816. J. Korean Chem. Soc. 1987, 30, 192-197.

41. Mei Feng, X.; Ostenfeld Larsen, T.; Schnürer, J. Production of volatile compounds by Rhizopus oligosporus during soybean and barley tempeh fermentation. Int. J. Food Microbiol. 2007, 113, 133-141. [CrossRef]

42. Schindler, S.; Krings, U.; Berger, R.G.; Orlien, V. Aroma development in high pressure treated beef and chicken meat compared to raw and heat treated. Meat Sci. 2010, 86, 317-323. [CrossRef] [PubMed]

43. Wettasinghe, M.; Vasanthan, T.; Temelli, F.; Swallow, K. Volatile flavour composition of cooked by-product blends of chicken, beef and pork: A quantitative GC-MS investigation. Food Res. Int. 2001, 34, 149-158. [CrossRef]

44. Frank, D.; Hughes, J.; Piyasiri, U.; Zhang, Y.; Kaur, M.; Li, Y.; Mellor, G.; Stark, J. Volatile and non-volatile metabolite changes in 140-day stored vacuum packaged chilled beef and potential shelf life markers. Meat Sci. 2020, 161, 108016. [CrossRef]

45. Estévez, M.; Morcuende, D.; Ventanas, S.; Cava, R. Analysis of Volatiles in Meat from Iberian Pigs and Lean Pigs after Refrigeration and Cooking by Using SPME-GC-MS. J. Agric. Food Chem. 2003, 51, 3429-3435. [CrossRef] [PubMed]

46. Torres-Penaranda, A.V.; Reitmeier, C.A.; Wilson, L.A.; Fehr, W.R.; Narvel, J.M. Sensory Characteristics of Soymilk and Tofu Made from Lipoxygenase-Free and Normal Soybeans. J. Food Sci. 1998, 63, 1084-1087. [CrossRef]

47. Yang, A.; Smyth, H.; Chaliha, M.; James, A. Sensory quality of soymilk and tofu from soybeans lacking lipoxygenases. Food Sci. Nutr. 2016, 4, 207-215. [CrossRef]

48. Kustyawati, M.E.; Nawanish, O.; Nurdjanah, S. Profile of aroma compounds and acceptability of modified tempeh. Int. Food Res. J. 2017, 24, 734-740.

49. Eriksson, C.E.; Lundgren, B.; Vallentin, K. Odor dectectability of aldehydes and alcohols orginating from lipid oxidation. Chem. Senses 1976, 2, 3-15. [CrossRef]

50. Leejeerajumnean, A.; Duckham, S.C.; Owens, J.D.; Ames, J.M. Volatile compounds in Bacillus-fermented soybeans. J. Sci. Food Agric. 2001, 81, 525-529. [CrossRef]

51. Besson, I.; Creuly, C.; Gros, J.B.; Larroche, C. Pyrazine production by Bacillus subtilis in solid-state fermentation on soybeans. Appl. Microbiol. Biotechnol. 1997, 47, 489-495. [CrossRef]

52. Cerny, C.; Grosch, W. Precursors of ethyldimethylpyrazine isomers and 2,3-diethyl-5-methylpyrazine formed in roasted beef. Z. Lebensm. Unters. Forsch. 1994, 198, 210-214. [CrossRef]

53. Cerny, C.; Grosch, W. Evaluation of potent odorants in roasted beef by aroma extract dilution analysis. Z. Lebensm. Unters. Forsch. 1992, 194, 322-325. [CrossRef]

54. Frank, D.; Raeside, M.; Behrendt, R.; Krishnamurthy, R.; Piyasiri, U.; Rose, G.; Watkins, P.; Warner, R. An integrated sensory, consumer and olfactometry study evaluating the effects of rearing system and diet on flavour characteristics of Australian lamb. Anim. Prod. Sci. 2017, 57, 347-362. [CrossRef]

55. Frank, D.; Watkins, P.; Ball, A.; Krishnamurthy, R.; Piyasiri, U.; Sewell, J.; Ortuno, J.; Stark, J.; Warner, R. Impact of Brassica and Lucerne Finishing Feeds and Intramuscular Fat on Lamb Eating Quality and Flavor. A Cross-Cultural Study Using Chinese and Non-Chinese Australian Consumers. J. Agric. Food Chem. 2016, 64, 6856-6868. [CrossRef] [PubMed]

56. Zachariah, T.J.; Leela, N.K. 11-Volatiles from herbs and spices. In Handbook of Herbs and Spices; Peter, K.V., Ed.; Woodhead Publishing: Sawston, UK, 2006; pp. 177-218. [CrossRef] 
57. Shahidi, F.; Pegg, R.B. Hexanal as an indicator of meat flavor deterioration. J. Food Lipids 1994, 1, 177-186. [CrossRef]

58. Jayasena, D.D.; Ahn, D.U.; Nam, K.C.; Jo, C. Flavour chemistry of chicken meat: A review. Asian Australas J. Anim. Sci. 2013, 26, 732-742. [CrossRef]

59. Arihara, K. Strategies for designing novel functional meat products. Meat Sci. 2006, 74, 219-229. [CrossRef]

60. Williams, P. Nutritional composition of red meat. Nutr. Diet. 2007, 64, S113-S119. [CrossRef]

61. Fuke, S. Taste-active components of seafoods with special reference to umami substances. In Seafoods: Chemistry, Processing Technology and Quality; Shahidi, F., Botta, J.R., Eds.; Springer: Boston, MA, USA, 1994; pp. 115-139. [CrossRef]

62. Zeisel, S.H.; Da Costa, K.-A.; Franklin, P.D.; Alexander, E.A.; Lamont, J.T.; Sheard, N.F.; Beiser, A. Choline, an essential nutrient for humans. FASEB J. 1991, 5, 2093-2098. [CrossRef]

63. Ichimura, S.; Nakamura, Y.; Yoshida, Y.; Hattori, A. Hypoxanthine enhances the cured meat taste. Anim. Sci. J. 2017, 88, 379-385. [CrossRef]

64. Lee, Y.-C.; Chi, M.-C.; Lin, M.-G.; Chen, Y.-Y.; Lin, L.-L.; Wang, T.-F. Biocatalytic Synthesis of $\gamma$-glutamyl-L-leucine, a KokumiImparting Dipeptide, by Bacillus licheniformis $\gamma$-Glutamyltranspeptidase. Food Biotechnol. 2018, 32, 130-147. [CrossRef]

65. Beaumont, M. Flavouring composition prepared by fermentation with Bacillus spp. Int. J. Food Microbiol. 2002, 75, 189-196. [CrossRef]

66. Utami, R.; Wijaya, C.H.; Lioe, H.N. Taste of Water-Soluble Extracts Obtained from Over-Fermented Tempe. Int. J. Food Prop. 2016, 19, 2063-2073. [CrossRef]

67. Watkins, P.J.; Frank, D.; Singh, T.K.; Young, O.A.; Warner, R.D. Sheepmeat flavor and the effect of different feeding systems: A review. J. Agric. Food Chem. 2013, 61, 3561-3579. [CrossRef] [PubMed]

68. Methven, L. 4-Natural food and beverage flavour enhancer. In Natural Food Additives, Ingredients and Flavourings; Baines, D., Seal, R., Eds.; Woodhead Publishing: Sawston, UK, 2012; pp. 76-99. [CrossRef]

69. Minkiewicz, P.; Iwaniak, A.; Darewicz, M. BIOPEP-UWM Database of bioactive peptides: Current opportunities. Int. J. Mol. Sci. 2019, 20, 5978. [CrossRef] [PubMed]

70. Tamam, B.; Syah, D.; Suhartono, M.T.; Kusuma, W.A.; Tachibana, S.; Lioe, H.N. Proteomic study of bioactive peptides from tempe. J. Biosci. Bioeng. 2019, 128, 241-248. [CrossRef] [PubMed]

71. Žugčić, T.; Abdelkebir, R.; Barba, F.J.; Rezek-Jambrak, A.; Gálvez, F.; Zamuz, S.; Granato, D.; Lorenzo, J.M. Effects of pulses and microalgal proteins on quality traits of beef patties. J. Food Sci. Technol. 2018, 55, 4544-4553. [CrossRef] [PubMed] 